\title{
Time-related action of Lactobacillus plantarum in the bacterial microbiota of shrimp digestive tract and its action as immunostimulant
}

\author{
Felipe do Nascimento Vieira ${ }^{(1)}$, Celso Carlos Buglione Neto(1), José Luiz Pedreira Mouriño(1), Adolfo Jatobá(1), \\ Cristina Ramirez $z^{(2)}$, Maurício Laterça Martins ${ }^{(3)}$, Margherita Anna Antonia Maria Barracco ${ }^{(4)}$ and Luis Alejandro Vinatea ${ }^{(1)}$ \\ (1)Universidade Federal de Santa Catarina (UFSC), Departamento de Aqüicultura, Laboratório de Camarões Marinhos, Caixa Postal 10.136, \\ CEP 88062-601 Florianópolis, SC, Brazil. E-mail: felipenvieira@yahoo.com.br, celsocbneto@yahoo.com.br, mourino@lcm.ufsc.br, \\ adjatoba@yahoo.com.br, vinatea@mbox1.ufsc.br (2)Universidad del Valle, Ciudad Universitaria Melendez, Calle 13, 100-00 Cali, Colombia. \\ E-mail: crisrami123@gmail.com (3)UFSC, Departamento de Aqüicultura, Núcleo de Diagnóstico e Patologia em Aqüicultura, Caixa Postal 476, \\ CEP 88040-900 Florianópolis, SC, Brazil. E-mail: mlaterca@cca.ufsc.br (4)UFSC, Departamento de Biologia Celular, Embriologia e Genética, \\ Laboratório de Imunologia Aplicada à Aqüicultura, Caixa Postal 476, CEP 88040-900 Florianópolis, SC, Brazil. E-mail: barracco@mbox1.ufsc.br
}

\begin{abstract}
The objective of this work was to assess the time-related action of probiotic Lactobacillus plantarum in the bacterial microbiota of the digestive tract of Litopenaeus vannamei, and the relation of total haemocyte count and serum phenol oxidase activity of shrimp challenged with Vibrio harveyi. Shrimps were fed with a probiotic-supplemented diet, for eight days, then shifted to a commercial diet. Shrimps fed only with the commercial diet served as control. Evaluations were made on the $8^{\text {th }}$ day of experiment and repeated two, four, six and eight days later. Total lactic bacteria in the digestive tract was higher until the $4^{\text {th }}$ day of evaluation in the probioticsupplemented group. Vibrio spp. counts were higher in the control at days zero and two. Until the $4^{\text {th }}$ day of evaluation, the total haemocyte counts in shrimps after challenge with $V$. harveyi were higher in probioticsupplemented group than in control group. Significant difference was not observed in phenol oxidase activity. On the $6^{\text {th }}$ day after shifting from supplemented to control diet, all parameters were equal in both groups, suggesting that the time-related action of $L$. plantarum in shrimp is short.
\end{abstract}

Index terms: Litopenaeus vannamei, Vibrio harveyi, total haemocyte count, lactic bacteria, phenol oxidase, probiotic.

\section{Tempo de atuação de Lactobacillus plantarum na microbiota bacteriana intestinal de camarão e sua ação como imunoestimulante}

\begin{abstract}
Resumo - O objetivo deste trabalho foi avaliar o tempo de atuação de Lactobacillus plantarum, na microbiota bacteriana intestinal de Litopenaeus vannamei, e sua relação com a contagem total de hemócitos e a atividade da fenoloxidase após a exposição a Vibrio harveyi. Os camarões foram alimentados com dieta suplementada com probióticos por oito dias e, depois, substituída por dieta comercial. Os camarões alimentados com dieta comercial constituíram o controle. As avaliações foram realizadas no oitavo dia de experimento e repetidas dois, quatro, seis e oito dias depois. A contagem total de bactérias lácticas no intestino foi maior até o quarto dia de avaliação, no grupo alimentado com probióticos. A contagem de Vibrio spp. foi superior no grupo controle nos dias zero e dois. Até o quarto dia, a contagem total de hemócitos dos camarões após a inoculação de $V$. harveyi foi superior no grupo alimentado com probiótico em relação ao grupo controle. Não foi observada diferença na atividade da fenoloxidase. No sexto dia, após a substituição da dieta suplementada com probióticos por dieta controle, todos os parâmetros avaliados foram iguais nos dois grupos, o que indica que o tempo de atuação de L. plantarum em camarões é curto.
\end{abstract}

Termos para indexação: Litopenaeus vannamei, Vibrio harveyi, contagem total de hemócitos, bactérias lácticas, fenoloxidase, probiótico.

\section{Introduction}

Massive mortalities and economic losses in shrimp farming are beyond calculations; they are caused by diseases, mainly of viral origin such as white spot syndrome virus (WSSV), taura syndrome virus (TSV) and yellow head virus (YHV). Opportunistic bacterial infections also cause serious losses in marine shrimp 
farming, and several Vibrio species have been reported as pathogenic (Lightner \& Redman, 1998).

In order to control Vibrio sp. and other pathogenic bacteria, prophylactic and therapeutic use of antibiotics is the most common strategy in aquaculture (Gomez-Gil et al., 2000). However, antibiotics are environmental pollutants, and pathogenic bacteria can easily develop resistance to them (Karunasagar et al., 1994). Moreover, importers and consumers have become restrictive and averse to commodities produced with the use of antibiotics. Recently, an alternative that has been widely employed in the industry is the dietary supplementation with probiotic bacteria (Farzanfar, 2006).

Gatesoupe (1999) defines probiotics as live microbial cells administered to cultured organisms to colonize the digestive tract and improve their immune response. Lactobacillus is among the most studied genera of probiotic bacteria, because they produce several antimicrobial compounds like antimicrobial peptides, organic acids and hydrogen peroxide (Fooks \& Gibson, 2002).

Probiotics administered directly in the diet modify the bacterial microbiota of marine shrimp digestive tract (Ziaei-Nejad et al., 2006), and stimulate the host immune response against harmful pathogens (Rengpipat et al., 2000). Nevertheless, the period in which bacterial microbiota of shrimp digestive tract remains modified, and the interval in which the immune system is stimulated after probiotic administration is still unknown. Lactobacillus plantarum has already been reported to enhance Litopenaeus vannamei larvae survival and resistance to Vibrio harveyi challenge (Vieira et al., 2007).

Modulation of phenol oxidase (PO) activity has been widely used as a health indicator in shrimp (Rodríguez \& Le Moullac, 2000); PO catalyzes the oxidation of phenolic compounds into quinones, which can be polymerized into melanin. Melanin and other intermediate compounds of the melanogenesis cascade are toxic to microorganisms (Nappi \& Vass, 1993). Phenol oxidase activity seems to vary according to stress conditions such as in a pathogen infection (Rodríguez \& Le Moullac, 2000).

The objective of this work was to assess the time of action of the probiotic L. plantarum, in the bacterial microbiota of shrimp digestive tract, and the relation of total haemocyte count and serum phenol oxidase activity in shrimp challenged with $V$. harveyi.

\section{Materials and Methods}

The experiment was carried out at the Laboratório de Patologia Aplicada à Aquiicultura and at the Laboratório de Cultivo de Camarões Marinhos, of the Departamento de Aqüicultura, Universidade Federal de Santa Catarina (UFSC), in association with the Laboratório de Imunologia Aplicada à Aqüicultura, Departamento de Biologia Celular, Embriologia e Genética, UFSC, in July 2006.

Juvenile $L$. vannamei shrimps, with $10 \pm 1.23 \mathrm{~g}$ body weight, hatched at the Laboratório de Cultivo de Camarões Marinhos, were used for the experiment. The lactic acid bacterium L. plantarum was isolated from $30 \pm 3 \mathrm{~g} \mathrm{~L}$. vannamei broodstock shrimps, reared at the same laboratory (Vieira et al., 2007). This bacteria was identified based on a series of physiological and biochemical parameters (Kit API 50CH). This identification was confirmed by $16 \mathrm{~S}$ rRNA gene sequencing, and $L$. plantarum was maintained in the microorganisms collection of Centro Pluridisciplinar de Pesquisas Químicas, Biológicas e Agrícolas, of Universidade Estadual de Campinas (Unicamp), Brazil, under 00707 DRM01. The pathogenic bacteria strain used was $V$. harveyi ATCC 14126.

The probiotic bacterium L. plantarum was cultured in man rogosa sharpe medium (MRS), and was incubated under continuous agitation of $200 \mathrm{rpm}$ at $35^{\circ} \mathrm{C}$ for 24 hours, in order to reach the concentration of $10^{9} \mathrm{CFU} \mathrm{mL}^{-1}$.

The pathogenic bacterium $V$. harveyi was cultured in brain heart infusion medium (BHI), under continuous agitation of $200 \mathrm{rpm}$ at $30^{\circ} \mathrm{C}$ for 24 hours, and then it was centrifuged at $1,000 \mathrm{~g}$. The supernatant was discarded, and the bacterial pellet was resuspended in sterile saline solution $1.5 \%$ of $\mathrm{NaCl}$ (SSS). Bacterial concentration was estimated by counting the colonies formed on the plates of trypticase soy agar culture medium (TSA), after eight serial dilutions, factor 10. Inoculum concentration was adjusted to $10^{7} \mathrm{CFU} \mathrm{mL}^{-1}$ with $1.5 \%$ saline solution.

Two hundred milliliters of the lactic acid bacteria inoculum $\left(10^{8} \mathrm{CFU} \mathrm{mL} \mathrm{m}^{-1}\right)$ were sprayed per kilogram of a commercial diet (35\% crude protein). Probiotic incorporated diet was hermetically incubated, without air presence, at $35^{\circ} \mathrm{C}$ for 24 hours, for pellet colonization. The control diet was sprayed with sterile culture medium. Both diets were transferred to a forced air oven to dry at $35^{\circ} \mathrm{C}$ for 24 hours. 
Three samples $(1 \mathrm{~g})$ of the dried diet were macerated in $1 \mathrm{~mL}$ of sterile saline solution $(1.5 \%)$ and serially diluted nine times (1/10). Dilutions between $10^{-5}$ and $10^{-9}$ were grown in MRS culture medium at $35^{\circ} \mathrm{C}$ for 48 hours, in order to estimate the probiotic concentration $\left(1.5 \pm 0.7 \times 10^{8} \mathrm{CFU} \mathrm{g}^{-1}\right)$.

For the experiment, 400 juvenile shrimps with $10 \pm 1.2 \mathrm{~g}$ body weight were randomly placed in eight $120 \mathrm{~L}$ tanks (50 shrimps per tank), for the probiotic and control groups. Water temperature was kept at $28 \pm 2{ }^{\circ} \mathrm{C}$ and salinity at $30 \%$. Bottom sediment removal and $10 \%$ water exchange were adopted for eight days, when $100 \%$ of the water was renovated to eliminate microbiota.

Shrimps from the control group (C) were fed with control diet throughout the experiment, and shrimps from the probiotic group $(\mathrm{P})$ were fed with probiotic diet for eight days, and then shifted to a commercial diet. Shrimps from both groups were fed with $3 \%$ of body weight four times a day (at $8,12,16$ and $20 \mathrm{~h}$ ). The experiment was conducted in a completely randomized design, with four replicates.

Eight days after the start of feeding with probioticsupplemented diet, three shrimps were randomly sampled from each tank for microbiological analysis of the digestive tract $(n=24$; eight pools with three shrimps each). Other three shrimps from each tank were challenged with $V$. harveyi $(25 \mu \mathrm{L}$ SSS with $10^{7} \mathrm{CFU} \mathrm{mL}-1$ injected in the first abdominal segment) and, then, samples were transferred to containers with $15 \mathrm{~L}$ of seawater at $30 \%$ salinity. Other three shrimps per tank were injected with $25 \mu \mathrm{L}$ SSS and transferred to $15 \mathrm{~L}$ of $30 \%$ seawater, serving as negative controls. Three hours after challenge (time based on previous trials, when shrimp mortality was not observed), shrimp haemolymph (16 pools with three shrimps each) was collected for total haemocyte counts (THC), phenol oxidase (PO) activity and bacterial count, and, then, shrimps were sacrificed. These procedures were repeated two, four, six and eight days after the probiotic group was shifted to commercial diet.

Haemolymph was collected from the ventral sinus of the shrimp (c.a. $300 \mu \mathrm{L}$ per shrimp). Samples were collected with $1 \mathrm{~mL}$ sterile syringe $(21 \mathrm{G})$ at $4^{\circ} \mathrm{C}$. After collection, $10 \mu \mathrm{L}$ subsamples were fixed in $4 \%$ formalinMAS solution ( $27 \mathrm{mM}$ sodium citrate, $336 \mathrm{mM} \mathrm{NaCl}$, $115 \mathrm{mM}$ glucose, $9 \mathrm{mM}$ EDTA, $\mathrm{pH}$ 7), in order to determine total haemocyte count (THC). Another $10 \mu \mathrm{L}$ subsample was used for microbiological analysis, and the remaining haemolymph was left to clot on ice. The clot was then frozen and thawed three times, repeatedly centrifuged at $10,000 \mathrm{~g}$ for $10 \mathrm{~min}$ to obtain the serum, which was aliquoted and stored at $-20^{\circ} \mathrm{C}$.

For digestive tract and haemolymph microbiological analyses, sampled haemolymph $(10 \mu \mathrm{L})$ was spread under sterile conditions on Petri dishes with thiosulphate citrate bile salt sucrose agar culture medium (TCBS) to check for Vibrio sp. The digestive tracts of the three sampled shrimps were removed with tweezers and scalpel, and weighed and homogenized with SSS in a mortar and serially diluted (1/10) five times. Dilutions were spread in the following culture media: marine agar (nonselective agar, total bacteria count), MRS agar (lactic bacteria selective, $\mathrm{pH}$ adjusted to 5.5), and TCBS agar (Vibrio spp. selective), and incubated at $30^{\circ} \mathrm{C}$. Total colon forming units were counted 24 hours after incubation, in marine agar and TCBS agar and, 48 hours after incubation, in MRS agar. Gram staining was performed with the colonies grown in MRS.

Total haemocyte count was determined directly using a Neubauer chamber. Serum protein concentration was determined according to Bradford method (Bradford, 1976) using bovine serum albumin (BSA) as standard.

Phenol oxidase activity was detected through spectrophotometry $(490 \mathrm{~nm})$ by the formation of the pigment DOPA-chrome, after oxidation of the substrate L-dihydroxyphenylalanine (L-DOPA); serum samples (eight pools with three shrimps each) were diluted (1:9) in TBS ( $1 \mathrm{mM}$ Tris, $336 \mathrm{mM} \mathrm{NaCl}, 5 \mathrm{mM} \mathrm{CaCl}_{2}$,

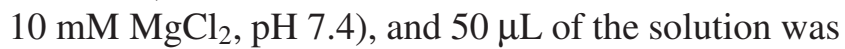
incubated in triplicate with $50 \mu \mathrm{L}$ of enzyme inducer trypsin $\left(1 \mathrm{mg} \mathrm{L}^{-1}\right)$, for $5 \mathrm{~min}$ in 96-microwell plates. After incubation, $50 \mu \mathrm{L}$ of L-DOPA ( $\left.3 \mathrm{mg} \mathrm{mL}^{-1}\right)$ was added in each well. Control was made with $100 \mu \mathrm{L}$ TBS added to $50 \mu \mathrm{L}$ of the 1:9 diluted serum in TBS. DOPA-chrome formation was monitored after 0,5 and $10 \mathrm{~min}$. One unit of enzymatic activity is equivalent to a variation of 0.001 in the absorbance per min per milligram of protein (Söderhäll \& Hall, 1984).

Repeated measures ANOVA were used (at 5\% probability) for the digestive tract microbiology. Phenol oxidase (PO) activity, total haemocyte count (THC) and bacterial count in the shrimp haemolymph were analyzed by two-way (2x2) ANOVA with repeated measures. Factor A levels were $(\mathrm{P})$ probiotic group and $(\mathrm{C})$ control group; and factor B levels were (V) challenged with $V$. harveyi and (S) negative control with sterile saline solution. When analysis of variance indicated difference 
among factors, Tukey test was used at $5 \%$ probability. Microbial counts of the digestive tract from the probiotic group were analyzed by exponential regression. THC and PO activity were analyzed by linear regression for the probiotic group challenged with $V$. harveyi. Microbiological counts and THC were $\log (\mathrm{x}+1)$ transformed.

\section{Results and Discussion}

No significant difference was observed for total bacteria in shrimp digestive tract, but Vibrio spp. counts were higher $(\mathrm{p}<0.05)$ for control group $(\mathrm{C})$ on the days zero and two (Figure 1). Vibrio spp. counts grew exponentially in the probiotic group after shifting to commercial diet.

Lactic bacteria count in the digestive tract was higher for the probiotic group until the day four $(\mathrm{p}<0.05)$, but it was not significant after day six (Figure 1), and reduced exponentially after shifting to commercial diet. Gram stain in the probiotic group revealed Gram-positive bacilli and cocci colonies grouped in pairs, morphologically similar to those bacteria used as probiotic, whereas the control group presented different types of Gram-positive bacteria, mostly cocci.

Except for terrestrial organisms, the bacterial population in the digestive tract of aquatic organisms is mainly constituted by Gram-negative bacteria (Farzanfar et al., 2006). Bacterial population may vary according to environmental changes (Gomez-Gil et al., 2000), lack of nutrient (Ringo \& Gatesoup, 1998) or by the use of probiotic bacteria (Rengpipat et al., 2000).

Diet supplementation with Gram-positive probiotic bacteria can reduce Vibrio bacteria population from shrimp digestive tract (Ziaei-Nejad et al., 2006). This is confirmed in this work, as lactic bacterium L. plantarum, supplemented in the diet, reduced the number of Vibrio spp. in the shrimp digestive tract, without influencing total bacteria count. This change in the bacterial microbiota of digestive tract can be beneficial to shrimp, as predominance of Vibrio spp. bacteria reduces shrimp growth (Yasuda \& Kitao, 1980).

Inhibition of bacterial proliferation by probiotic supplemented-diet is usually related to the production of inhibitory compounds (Ramirez et al., 2006) or to exclusive competition (Gomez-Gil et al., 2000). Li et al. (2006) reported that the probiotic bacterium strain Arthrobacter XE-7 inhibited V. parahaemolyticus, $V$. anguillarum and $V$. nereis as efficiently as the antibiotic chloramphenicol. Lactic bacteria produce several bactericidal compounds of high (bacteriocins) and low (reuterin) molecular weight (Ringo \& Gatesoupe, 1998), hydrogen peroxide (Sugita et al., 2007), lactic and acetic acids (Vázques et al., 2005), which can be associated to the inhibitory effects observed in the present work. However, L. plantarum strain does not seem to have high capacity of exclusive competition, as at the fourth day after shifting from probiotic diet to commercial diet there was no difference for Vibrio spp. counts, in the probiotic or control groups. On the day sixth, lactic bacteria represented only a low portion of the total bacteria population in the digestive tract, similar to the control group, which confirms the low competitiveness of the strain. Therefore, the native bacterial microbiota of digestive tract returns quickly to initial patterns, excluding the lactic acid bacteria. In this sense, the probiotic supplemented diet should be continuously provided to maintain high counts of lactic acid bacteria and low counts of Vibrio spp. in the shrimp digestive tract bacterial microbiota.
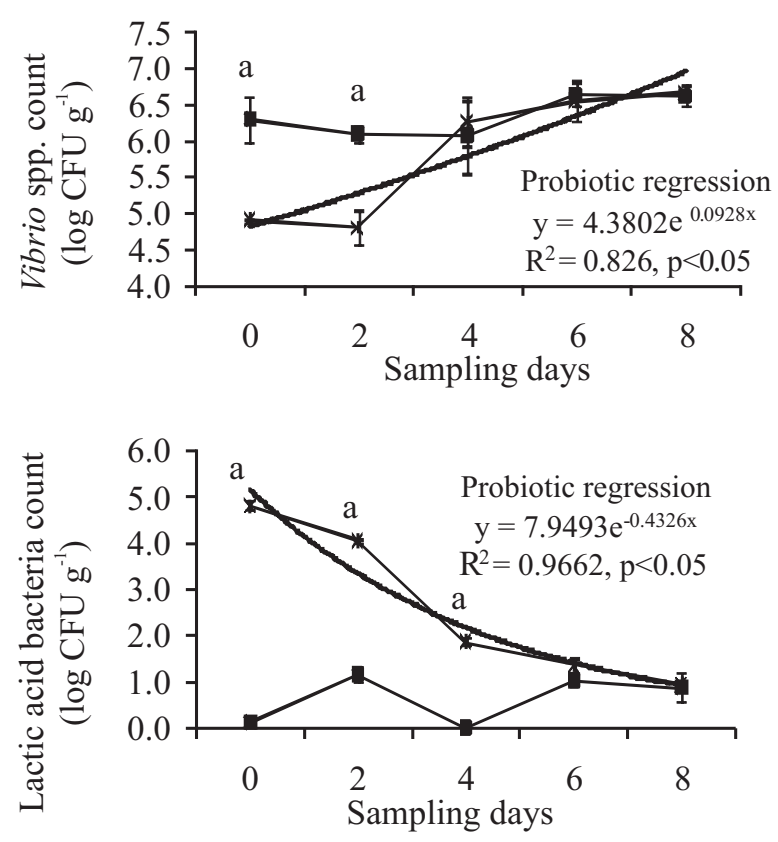

*-Probiotic - -Control -Exponential (Probiotic)

Figure 1. Total Vibrio spp. and total lactic acid bacteria in digestive tract of shrimps of the probiotic and control groups. Values are means \pm SE of four pools with three shrimps each. a: significant difference after Tukey mean comparison test, at $5 \%$ probability. 
Persistence of a bacterium strain in the digestive tract is affected by several factors, including dietary components (Ringo \& Gatesoupe, 1998). In this way, the dietary inclusion of substrates to promote lactic bacteria growth (prebiotics) can increase the permanence of such bacteria in the shrimp digestive tract.

Bacterial counts in the haemolymph after $V$. harveyi challenge ranged from $3.3 \times 10$ to $1.8 \times 10^{3} \mathrm{CFU} \mathrm{mL}^{-1}$, with no significant difference between the probiotic and the control groups in any of the evaluations $(p>0.05)$. Bacterial colonies grown from the haemolymph were sacarose-negative Gram-negative vibrios, similar to the inoculum ( $V$. harveyi). No bacteria were found in the haemolymph from negative control (shrimp infected with SSS).

Shrimp presents innate or nonspecific immune system, with integrated cellular and humoral immune responses, which protects from harmful microorganisms and assure body integrity (Bachère, 2003). This integrated action of the immune system efficiently reduces the concentration of bacteria directly introduced into the haemolymph (Braak et al., 2002).

THC of shrimps challenged with $V$. harveyi was lower $(\mathrm{p}<0.05)$ than the negative control, 11,000 $\pm 3,200$ and $17,000 \pm 3,000$ cells $\mathrm{mm}^{-3}$, respectively. On the day zero, THC of shrimps from the negative control of the probiotic (PS) and the control (CS) groups were not different from the THC of the probiotic group challenged with $V$. harveyi $(\mathrm{PV})$, but they were higher $(\mathrm{p}<0.05)$ than the THC of the control group challenged with $V$. harveyi $(\mathrm{CV})$. The same was observed on days two and four. On days six and eight, THC was not different between groups PS and CS, but it was higher than the THC of groups PV and CV (Figure 2).

THC of the PV group reduced linearly after shifting from the probiotic to commercial diet. No significant trends of increase or reduction in THC were observed in the other groups on the evaluation days (Figure 2).

$\mathrm{THC}$ is one of the most used parameters to describe health status in crustaceans (Bachère, 2003). In this work, THC of shrimps challenged with $V$. harveyi was lower than the negative control. This result seemed to be associated with an inflammatory response of haemocytes that leave the circulation and migrate to the site of injection (Braak et al., 2002). Additionally, haemocytes can aggregate into haemocytic nodules, in which cell adhesion molecules such as peroxinectin apprehend microorganisms between them (Jiravanichpaisal et al., 2006) and, then, are mechanically eliminated from the circulation through the gills (Martin et al., 2000). Haemocytes can also attach to other organs as the lymphoid organ (Braak et al., 2002) and the hepatopancreas (Alday-Sanz et al., 2002), thus, reducing the number of circulating haemocytes.

In the present work, THC in PV group was not as reduced as in the $\mathrm{CV}$ group at days zero, two and four. This may be due to a faster production of circulating haemocytes by the hematopoietic tissue of shrimps from the probiotic group (Braak et al., 2002). Another possibility is the fast haemocyte response to fight infection, which resulted in a slight reduction in the number of circulating haemocytes three hours after challenge.

Phenol oxidase activity varied from 20 to $57 \mathrm{U}$ per min per $\mathrm{mg}$ protein, and was higher $(\mathrm{p}<0.05)$ in the $V$. harveyi
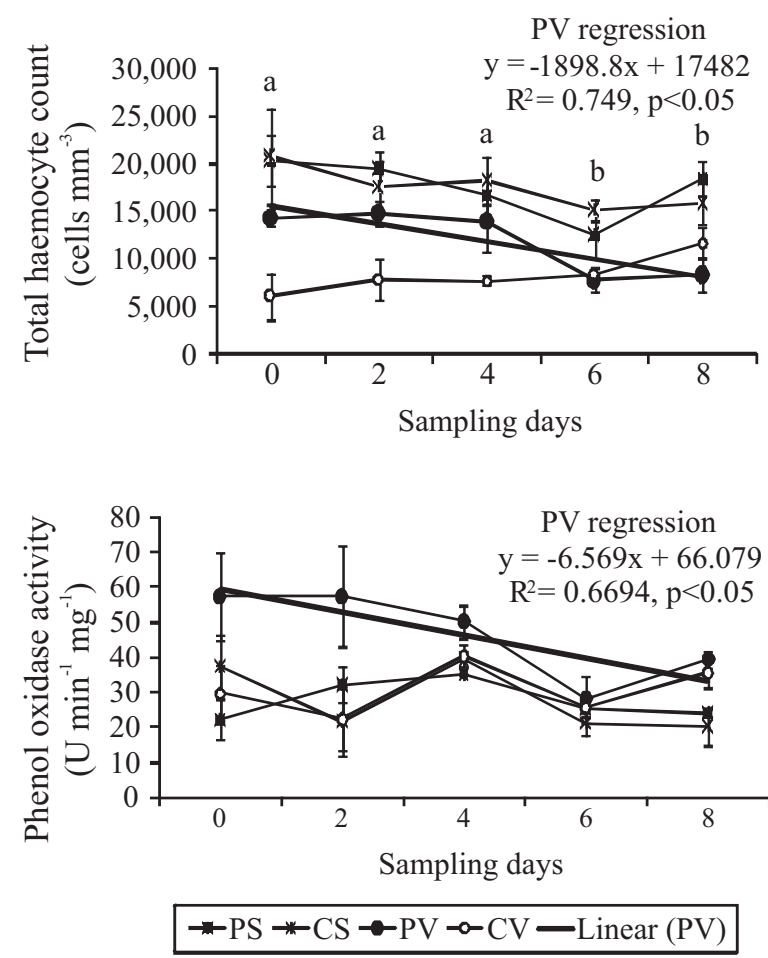

Figure 2. Total haemocyte count and phenol oxidase activity three hours after Vibrio harveyi challenge and negative control of probiotic and control groups. PS: probiotic group, challenge negative control; PV: probiotic group $V$. harveyi challenged; CS: control group, challenge negative control; CV: control group $V$. harveyi challenged. Values are means $\pm \mathrm{SE}$ of four pools with three shrimps each. a: treatment PS is equal to CS and PV, and is different from CV by Tukey test, at $5 \%$ probability; b: treatment PS is equal to CS and is different from PV and CV by Tukey test, at $5 \%$ probability. 
challenged group than in the negative control group with $38 \pm 1.4$ and $28 \pm 0.7 \mathrm{U}$ per min per $\mathrm{mg}$ protein, respectively. No significant difference $(\mathrm{p}>0.05)$ was observed between $\mathrm{PO}$ activity in the probiotic and control groups, but there was a linear reduction in the PV group. No significant trends of increase or reduction in the PO activity were observed in the other groups during the evaluations (Figure 2).

Minimum amounts of lipopolysaccharides (LPS) of Gram-negative bacteria cell wall activate the enzyme proform system (ProPO) to its active form PO, which results in melanin production (Sritunyalucksana \& Söderhäll, 2000). Higher PO activity in V. harveyi challenged shrimps can be related to the production of PO after challenge, as seen with shrimps treated with immunostimulants (Yeh et al., 2006) and probiotics (Rengpipat et al., 2000). Although PO activity of PV group tended to be higher on days zero and two in the present work, it was not possible to detect differences in the PO activity between probiotic and control groups, most probably due to high variation in the enzyme activity.

Several bacteria from the genus Vibrio produce exotoxins (Austin \& Zhang, 2006), which can be immunosuppressive to shrimp. Therefore, the exponential increase in Vibrio spp. counts in shrimp digestive tract, when shifting from probiotic diet to the commercial one, can be related to the linear reduction in THC and PO activity after $V$. harveyi challenge. This result can also be a consequence of the exponential reduction in the lactic bacteria count in the digestive tract, as they are known to produce extra cellular compounds, which stimulate nonspecific immune responses (Marteau, 2002). Some studies suggest the same for marine shrimp. Chiu et al. (2007) reported that feeding with L. plantarum supplemented diet modified some immunological parameters in L. vannamei including PO and THC. Li et al. (2007) reported the same results for L. vannamei fed with Bacillus licheniformis supplemented diet to PO and THC. Itami et al. (1998) reported that the dietary administration of peptidoglycans, isolated from lactic bacterium Bifidobacterium thermophilum, enhanced the immunological parameters of Penaeaus japonicus and the resistance to $V$. penaeicida infection. Peptidoglycans of the L. plantarum cell wall could also stimulate the immune system, but as the lactic bacteria population was reduced, immune response may as well be endangered.

\section{Conclusion}

The time-related action of Lactobacillus plantarum in the bacterial microbiota of Litopenaeus vannamei digestive tract and its action as an immunostimulant are short (only six days).

\section{Acknowledgements}

To Elpídio Beltrame (in memoriam), for aid to the work achievement; to Professor Carla Bonetti, Universidade Federal de Santa Catarina (UFSC), Brazil, for providing access to the equipment in the Laboratório de Oceanografia Costeira; to Delano Schleder, from UFSC, for assistance in the immunological techniques; to Coordenação de Aperfeiçoamento de Pessoal de Nível Superior, for scholarship granted; to Secretaria Especial de Aqüicultura e Pesca, for financial support.

\section{References}

ALDAY-SANZ, V.; ROQUE, A.; TURNBULL, J.F. Clearing mechanisms of Vibrio vulnificus biotype I in the black tiger shrimp Penaeus monodon. Disease of Aquatic Organisms, v.48, p.91-99, 2002.

AUSTIN, B.; ZHANG, X.H. Vibrio harveyi: a significant pathogen of marine vertebrates and invertebrates. Letters in Applied Microbiology, v.43, p.119-124, 2006.

BACHÈRE, E. Anti-infectious immune effectors in marine invertebrates: potential tools for disease control in larviculture. Aquaculture, v.227, p.427-438, 2003.

BRAAK, C.B.T. van de; BOTTERBLOM, M.H.A.; TAVERNE, N.; MUISWINKEL, W.B. van; ROMBOUT, J.H.W.M.; KNAAP, W.P.W. van der. The roles of haemocytes and the lymphoid organ in the clearance of injected Vibrio bacteria in Penaeus monodon shrimp. Fish and Shellfish Immunology, v.13, p.293-309, 2002.

BRADFORD, M.M. A rapid and sensitive method for the quantitation of microgram quantities of protein utilizing the principle of protein-dye binding. Annals of Biochemistry, v.72, p.248-254, 1976.

CHIU, C.H.; GUU, Y.K.; LIU, C.H.; PAN, T.M.; CHENG, W. Immune responses and gene expression in white shrimp, Litopenaeus vannamei, induced by Lactobacillus plantarum. Fish and Shellfish Immunology, v.23, p.364-377, 2007.

FARZANFAR, A. The use of probiotics in shrimp aquaculture. FEMS Immunology and Medical Microbiology, v.48, p.149-158, 2006.

FOOKS, L.J.; GIBSON, G.R. Probiotics as modulators of the gut flora. British Journal of Nutrition, v.88, p.39-49, 2002.

GATESOUPE, F.J. The use of probiotics in aquaculture. Aquaculture, v.180, p.147-165, 1999. 
GOMEZ-GIL, B.; ROQUE, A.; TURNBULL, J.F. The use and selection of probiotic bacteria for use in the culture of larval aquatic organisms. Aquaculture, v.191, p.259-270, 2000.

ITAMI, T.; ASANO, M.; TOKUSHIGE, K.; KUBONO, K.; NAKAGAWA, A.; TAKENO, N.; NISHIMURA, H.; MAEDA, M.; KONDO, M.; TAKAHASHI, Y. Enhancement of disease resistance of kuruma shrimp, Penaeus japonicus, after oral administration of peptidoglycan derived from Bifidobacterium thermophilum. Aquaculture, v.164, p.277-288, 1998.

JIRAVANICHPAISAL, P.; LEE, B.L.; SÖDERHÄLL, K. Cell-mediated immunity in arthropods: hematopoiesis, coagulation, melanization and opsonization. Immunobiology, v.211, p.213-236, 2006.

KARUNASAGAR， I.; PAI， R.; MALATHI， G.R.; KARUNASAGAR, I. Mass mortality of Penaeus monodon larvae due to antibiotic-resistant Vibrio harveyi infection. Aquaculture, v.128, p.203-209, 1994.

LI, J.; TAN, B.; MAI, K.; AI, Q.; ZHANG, W.; XU, W.; LIUFU, Z.; MA, H. Comparative study between probiotic bacterium Arthrobacter XE-7 and chloramphenicol on protection of Penaeus chinensis post-larvae from pathogenic vibrios. Aquaculture, v.253, p.140-147, 2006.

LI, K.; ZHENG, T.; TIAN, Y.; XI, F.; YUAN, J.; ZHANG, G.; HONG, H. Beneficial effects of Bacillus licheniformis on the intestinal microflora and immunity of the white shrimp, Litopenaeus vannamei. Biotechnology Letters, v.29, p.525-530, 2007.

LIGHTNER, D.V.; REDMAN, R.M. Shrimp diseases and current diagnostic methods. Aquaculture, v.164, p.201-220, 1998.

MARTEAU, P.; SEKSIK, P.; JIAN, R. Probiotics and intestinal health effects: a clinical perspective. British Journal of Nutrition, v.88, p.51-57, 2002.

MARTIN, G.G.; QUINTERO, M.; QUIGLEY, M.; KHOSROVIAN, H. Elimination of sequestered material from the gills of decapod crustaceans. Journal of Crustacean Biology, v.20, p.209-217, 2000.

NAPPI, A.J.; VASS, E. Melanogenesis and the generation of cytotoxic molecules during insect cellular immune reactions. Pigment Cell Research, v.6, p.117-126, 1993.

RAMÍREZ, C.; BOLÍVAR, G.; CIFFONI, E.; PANCHENIAK, E.F.R.; SOCCOL, C.R. Microorganismos lácticos probióticos para ser aplicados en la alimentación de larvas de camarón y peces como substituto de antibiótico. La Alimentación Latinoamericana, v.264, p.70-78, 2006.
RENGPIPAT, S.; RUKPRATANPORN, S.; PIYATIRATITIVORAKUL, S.; MENASAVETA, P. Immunity enhancement in black tiger shrimp (Penaeus monodon) by a probiont bacterium (Bacillus S11). Aquaculture, v.191, p.271-288, 2000.

RINGO, E.; GATESOUPE, F.J. Lactic acid bacteria in fish: a review. Aquaculture, v.160, p.177-203, 1998.

RODRÍGUEZ, J.; LE MOULLAC, G. State of the art of immunological tools and health control of penaeid shrimp. Aquaculture, v.191, p.109-119, 2000.

SÖDERHÄLL, K.; HALL, L. Lipopolysaccharide-induced activation of prophenoloxidase activating system in crayfish haemocyte lysate. Biochimica et Biophysica Acta, v.797, p.99-104, 1984.

SRITUNYALUCKSANA, K.; SÖDERHÄLL, K. The proPO and clotting system in crustaceans. Aquaculture, v.191, p.53-69, 2000.

SUGITA, H.; OHTA, K.; KURUMA, A.; SAGESAKA, T. An antibacterial effect of Lactococcus lactis isolated from the intestinal tract of the Amur catfish, Silurus asotus, Linnaeus. Aquaculture Research, v.38, p.1002-1004, 2007.

VÁZQUEZ, J.A.; GONZÁLEZ, M.P.; MURADO, M.A. Effects of lactic acid bacteria cultures on pathogenic microbiota from fish. Aquaculture, v.245, p.149-161, 2005.

VIEIRA, F.N.; PEDROTTI, F.S.; BUGLIONE NETO, C.C.; MOURIÑO, J.L.P.; BELTRAME, E.; MARTINS, M.L.; RAMIREZ, C.; ARANA, L.A.V. Lactic-acid bacteria increase the survival of marine shrimp, Litopenaeus vannamei, after infection with Vibrio harveyi. Brazilian Journal of Oceanography, v.55, p.251-255, 2007.

YASUDA, K.; KITAO, T. Bacterial flora in the digestive tract of prawns Penaeus japonicus. Aquaculture, v.19, p.229-234, 1980.

YEH, S.T.; LEE, C.S.; CHEN, J.C. Administration of hot-water extract of brown seaweed Sargassum duplicatum via immersion and injection enhances the immune resistance of white shrimp Litopenaeus vannamei. Fish and Shellfish Immunology, v.20, p.332-345, 2006.

ZIAEI-NEJAD, S.; REZAEI, M.H.; TAKAMI, G.A. LOVETT, D.L.; MIRVAGHEFI, A.R.; SHAKOURI, M. The effect of Bacillus spp. bacteria used as probiotics on digestive enzyme activity, survival and growth in the Indian white shrimp Fenneropenaeus indicus. Aquaculture, v.252, p.516-524, 2006. 